\title{
Safety Hijab Design for Engineering Practical Usage Among Students by Kansei Engineering Method
}

\author{
Ditha Nizaora*, Dwi Cahyadi, Etwin Fibrianie \\ Soeprapto \\ Design Department \\ Politeknik Negeri Samarinda \\ Samarinda, Indonesia \\ dithanizaora@polnes.ac.id,dwicahyadi@polnes.ac.id, \\ etwin.f@gmail.com
}

\author{
Raudah Ahmad, Sujiati Jepriani \\ Civil Engineering Department \\ Politeknik Negeri Samarinda \\ Samarinda, Indonesia \\ Sujiati_jepriani@polnes.ac.id, raudah@polnes.ac.id
}

\author{
Rizky S. P. Rinda \\ Mechanical Engineering Department \\ Politeknik Negeri Samarinda \\ Samarinda, Indonesia \\ rinda.rizky@polnes.ac.id
}

\begin{abstract}
Workshop activity has to follow the regulation of Occupational Health and Safety (OHS) in order to minimalize accident at the workplace. Every worker must put on Personal Protection Equipment (PPE) to prevent him/herself from hazards in the workshop. Some PPE are helmet, protective clothing, safety shoes, gloves, etc. However, Muslim women, who work on the workshop, have a problem because there is no certain safety hijab for the PPE standardized. This research aims to analyze the criteria of safety hijab design used for the part of PPE. The data were collected using Kansei Method, i.e. designing preliminary research, compiling Kansei words, drafting Semantic Differential (SD) questionnaire, distributing the SD I questionnaire, conducting statistics analysis I, collecting product sample, developing design based on customers' preferences. From the collecting data result, it could be concluded that the Kansei words for safety hijab were the ergonomic factors and syar'i factors.
\end{abstract}

Keywords-Occupational Health and Safety (OHS), Personal Protection Equipment (PPE), safety hijab, Kansei words, ergonomic, syar'i

\section{INTRODUCTION}

Health, safety and environment (HSE) refers to a branch, or department, within a company that is responsible for the observance and protection of occupational health and safety rules and regulations along with environmental protection. HSE is also often referred to as environmental health and safety (EHS) or safety, health and environment (SHE). Safety Engineering is an engineering discipline which assures that engineered systems provide acceptable levels of safety $[1,2]$.
Employers have duties concerning the provision and use of Personal Protective Equipment (PPE) at work. PPE is equipment that will protect the user against health or safety risks at work. It can include items such as safety helmets, gloves, eye protection, high-visibility clothing, safety footwear and safety harnesses [2]. It also includes respiratory protective equipment (RPE).

A low safety culture is characterized with low compliance with the use of PPE in every job done high risk. The emergence of a safety and health hazard is triggered by any activity have different risks such as operation of production machines, manufacture of raw materials, and transportation of materials production [2]. Industrial sector growth is increasing by the emergence of complex industrial processes driven by automation and heavy machinery therefore, potential impacts on organizations, humans and the environment need to be anticipated $[3,4]$.

In engineering education there are always practical activities, where students are directly involved in carrying out work activities. Even though it is only for practicum activities, students must wear complete PPE. Based on its function, there are several types of PPE used by workers, including: Headwear, Eye Protection, Respiratory Protection, Body Protection, ear protection, and safety belts. Each PPE has its respective functions.

In this case we will discuss the types of personal protective equipment for the head. The purpose of the head protector is to protect the head from collisions, falling objects from above the head or hard objects that float and slide in the air, are exposed to heat radiation, sparks and other hazards that may endanger the head area. For some types of head protection, it is also 
intended to protect the hair of the workers from being trapped by the rotating machines.

For women who wear hijab, the implementation of practicum, especially those directly related to machines and physical activities, must pay attention to unsafe actions and unsafe conditions. Unsafe action is unsafe and dangerous actions for workers, for example Mixing of Chemicals, Disposing of Trash at random places, Not Carrying Out Work Procedures Well, Working Jokingly, etc. Unsafe Condition: unsafe and dangerous conditions for workers, example Not Carrying Out Work Procedures Well.

Kansei Engineering is a tool which translating customer's feelings into concrete product parameters and provides support in future product design [5,6]. Method of Kansei Engineering is specifically used to analyze consumer's implicit needs and associate them with product design characteristic, so that a guide to design a new concept of product could be established [7].

Currently there is no safety hijab for engineers, they still use the hijab like usually. In practicing, some of them wear unsafe hijab because it is easily tangled with machines. Hijab also is uncomfortable when engineers practice construction.

Based on the above background, this study aims to design a safety hijab that is used during field practice. Design hijab must be in accordance with the principles of ergonomics and PPE, but still consider religious aspects and consider with consumer's feelings.

\section{LITERATURE REVIEW}

\section{A. Occupational Safety and Health}

Work accidents are accidents related to work relations in the company since the worker leaves the house for the workplace, during work hours and rest hours and when the worker leaves work. Work accidents are accidents related to work relations in the company since the worker leaves the house for the workplace, during working hours and rest hours and on his return from work to home via the usual road.

Occupational Safety and Health aims to make workers safe, healthy, productive, prosperous and strong competitive, so that production can run smoothly and not be interrupted by accidents and workers the sick or the unwell making it unproductive $[4,8,9]$. Work accidents can be causing illness, disability, engine failure, cessation of the production process, environmental damage, and expenses work accident. In general, an accident work occurs because of two causes, namely unsafe environment and unsafe actions that do not fulfill occupational safety and health $[10,11]$.

Indonesian Law (UU No. 1, 1970) Concerning Work Safety is not only applied in industry. But in school or college it must be applied, given its importance. Practical procedures in accordance with PPE principles should be followed by students during practice. Complete personal protective equipment must be completed before the $\mathrm{d}$ practice begins. The potential for work accidents can come from the lack of completeness of PPE or compliance with PPE procedures during practice [1].

Completeness of PPE in engineering practice are described:

- Headware is used to prevent and protect hair entangled by rotating machines and to protect the head from the danger of being hit by sharp or hard objects, the danger of falling objects or being hit by floating objects, protecting the fall of microorganisms, splashing corrosive chemicals, heat sunshine etc.

- Eye protection equipment is used to protect the eyes from splashes of corrosive chemicals, dust and small particles floating in the air, gases or vapors that can cause eye irritation, electromagnetic wave radiation, solar radiation heat, blows or collisions of hard objects, etc.

- Respiratory protection equipment is used to protect the inhaler from the risk of exposure to contaminated or toxic gases, vapors, dust, or air, corrosion or stimulation.

- Hand protective equipment is used to protect hands and other parts from sharp or scratched objects, chemicals, hot and cold objects, contact with electric currents.

- Protective clothing is used to protect all or part of the body from sparks, hot or cold temperatures, chemical liquids, etc.

- Safety Shoes is used to protect feet and other parts from hard objects, sharp objects, metal / glass, chemical solutions, hot objects, contact with electric currents.

- Ear protection devices are used to reduce the intensity of the sound that enters the ear.

- Safety belt.

\section{B. Hijab}

Hijab (Arabic: باجح hijāb) is an Arabic word meaning barrier or veil. The term hijab is actually as listed. In the Qur'an, when you ask them for something, ask from behind a veil. Initially the hijab was defined as a medium for conveying meaning and socio-culture, as well as affirming and shaping woman identity. Hijab has experienced rapid development all over the world. Its presence enters spaces that support visual culture, thus impacting the commodification of the hijab [12]. The use of the hijab in the past was limited as a religious identity for Muslim women, has now dissolved into a style of life, called hijab fashion [13].

In Islam the command to wear the hijab for women is clearly stated in the Al Quran, QS An Nuur 31, it is written that women should stick out their veil to cover their chest.

\section{Kansei Engineering and Principles of Ergonomic}

Kansei Engineering (KE) is a technology translate into consumer feelings product design [14]. Method it is a tool for 
identifying needs emotional and translate it into features real product. This method can also determine the most important product factors for subscriber. The purpose of KE is develop a winning product hearts and minds of users of these products [15]. KE targets to improve human well-being by looking into physiological and psychological aspects that contributes to satisfaction [5]. There are many variations of the hijab today. There is square hijab, Bergo, pashmina, and scarf hijab, Cape hijab, hijab instant, etc. what makes it varied is the material and design. The hijab that is used must be in accordance with syar' $i$ and ergonomics (delicious, comfortable, safe, healthy and effective).

Ergonomics is study about optimization, efficiency, health, safety, comfort and human convenience workplace, home and anywhere humans exist. Principles of ergonomics are utility, safety, comfortability, flexibility, and durability. The principle of utility means that each product produced has benefits for someone in supporting activities or needs maximally without experiencing difficulties or problems in their use. The principle of Safety means that each product has a useful function without risking the safety or loss of its users. And the last, the principle of flexibility means that ergonomics can be used for multiple conditions or functions.

\section{METHODS}

In this research, the case study raised is about making hijab safety design for school children who practice engineering. The researcher identifies the market and determines product criteria. This study applies the Kansei engineering method as a product design method to be made.

\section{A. Identity Market}

The object of the study was woman aged 15 - 25 years. The questionnaire was distributed online due to the Covid 19 pandemic conditions towards 65 respondents who study in the East Kalimantan region. Gap in this research focused on design safety hijab for student who have engineering practical.

\section{B. Data Processing}

Collecting kansei word from questionnaire and interview with customers.

\section{Semantic Differential Questionnaire}

Kansei words that have been collected previously paired with the opponent of kansei words.

\section{Statistical Analysis}

With SPSS16, the data from the questionnaire were tested for validity, reliability tests, and factor analysis test.

\section{E. Design}

Design criteria obtained from kansei analysis, then made a safety hijab design.

\section{FINDINGS AND DISCUSSION}

\section{A. Collect Kansei Word}

Kansei word collection is obtained from distributing questionnaires to users. From the results of questionnaire kansei words, 34 kansei words are obtained, then grouped into 10 similar groups.

The next step, kansei word is tested for validity and reliability with SPSS25. Kansei word collection is obtained from distributing questionnaires to users. From the results of the collection of kansei words, 46 kansei words are obtained which will then be classified based on 10 categories and finally will be used as the basis for making semantic differential I questionnaires. Category Classification of Kansei Word shown in Table 1. Category Classification is a method for reduce data by creating levels (levels) from main concept to sub-level concept.

TABLE I. CATEGORY ClassificATIONS

\begin{tabular}{|l|l|l|l|l|}
\hline comfortable & cool & & safety & Secure \\
\hline & suit & & & Safety \\
\hline & condolence & & & protection \\
\hline & comfort & & syar'i & Closeness \\
\hline fashionable & modish & & & Presentable \\
\hline & modern & & & tidy \\
\hline & Fashionable & & & neat \\
\hline Identity & specific & & & syar'i \\
\hline & indicate & & Functionality & Classic \\
\hline & uniformity & & & Standard \\
\hline & identity & & & functionality \\
\hline & motif & & & Multifunction \\
\hline & sign & & Ergonomic & Fit \\
\hline & logo & & & Health \\
\hline & symbol & & & effective \\
\hline Color & colorful & & & efficient \\
\hline & dark & & & ergonomic \\
\hline & Bright & & & Complicated \\
\hline Material & rigid & & & \\
\hline & shirt & & & \\
\hline & katun & & & \\
\hline & Soft & & & \\
\hline & & & \\
\hline
\end{tabular}

Next step is making a questionnaire semantics differential. The semantic differential technique involves presenting pairs of bipolar, or opposite, adjectives at either end of a series of scales. Pairs of semantics differential can be seen in Table 2 . After the semantics differential stage, the next step is to calculate the statistical value with SPSS16. Validity test using SPSS16 with 10 variables from the classification of kansei word categories, obtained valid results for each variable. The value of $R_{\text {table }}<R_{\text {count }}$ means the data is valid and can be used for further testing (Table.2). 
TABLE II. VALIDITY TEST

\begin{tabular}{|l|l|l|l|}
\hline \multicolumn{1}{|c|}{ Variable } & \multicolumn{1}{c|}{ R count } & \multicolumn{1}{c|}{ R table } & \multicolumn{1}{c|}{ Note } \\
\hline Comfortable (X1) & 0.691 & 0.266 & Valid \\
\hline Fashionable (X2) & 0.732 & 0.266 & Valid \\
\hline Identity (X3) & 0.789 & 0.266 & Valid \\
\hline Symbols (X4) & 0.724 & 0.266 & Valid \\
\hline Color(X5) & 0.762 & 0.266 & Valid \\
\hline Material (X6) & 0.776 & 0.266 & Valid \\
\hline Safety (X7) & 0.620 & 0.266 & Valid \\
\hline Syar'I (X8) & 0.690 & 0.266 & Valid \\
\hline Functional (X9) & 0.746 & 0.266 & Valid \\
\hline Ergonomic (X10) & 0.849 & 0.266 & Valid \\
\hline
\end{tabular}

Reliability focuses on consistency issues and more attention to accuracy problem. To find out the reliability value of the 10 measured variables is from the Cronbach alpha value. The data is reliable because Cronbach alpha 0. 903 (Table 3). If Cronbach alpha value $\geq 0.6$ then the variable is reliable.

\section{TABLE III. RELIABILITY SCORE}

\begin{tabular}{|l|l|}
\hline \multicolumn{2}{|c|}{ Reliability Statistics } \\
\hline Cronbach's Alpha & N of Items \\
\hline .903 & 10 \\
\hline
\end{tabular}

The next step is analyzed factor analysis with SPSS 25. factor analysis will be focus space in determining the items and product design categories based on image or feeling customers in the word kansei. From the results of this factor analysis (Fig. 1) it is known that in designing safety hijab based on feelings is influenced by 2 factors. That factors are grouping 10 existing variables into Ergonomics factor and Syar'I factor (table 4).

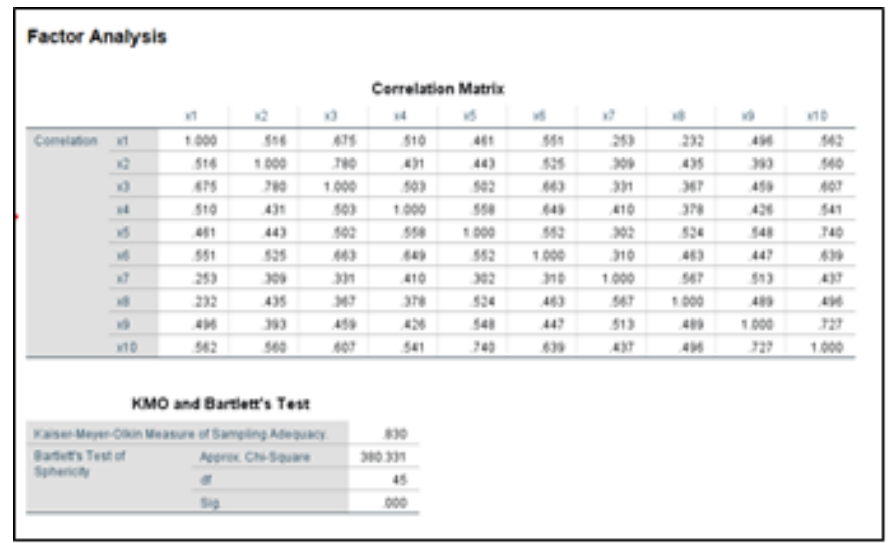

Fig. 1. Factor analysis.

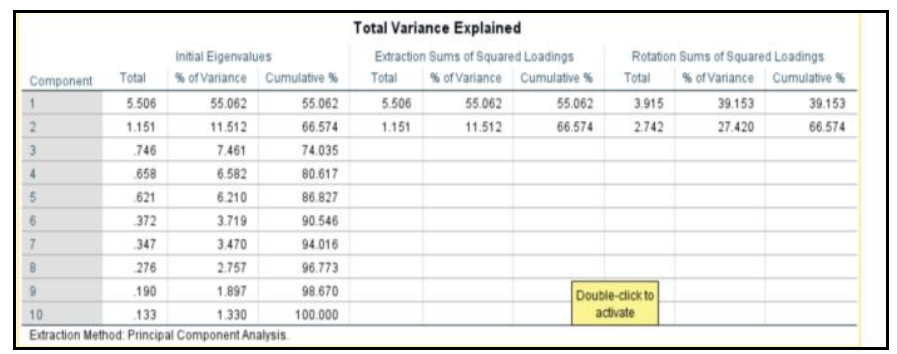

Fig. 2. Extraction eigen's value.

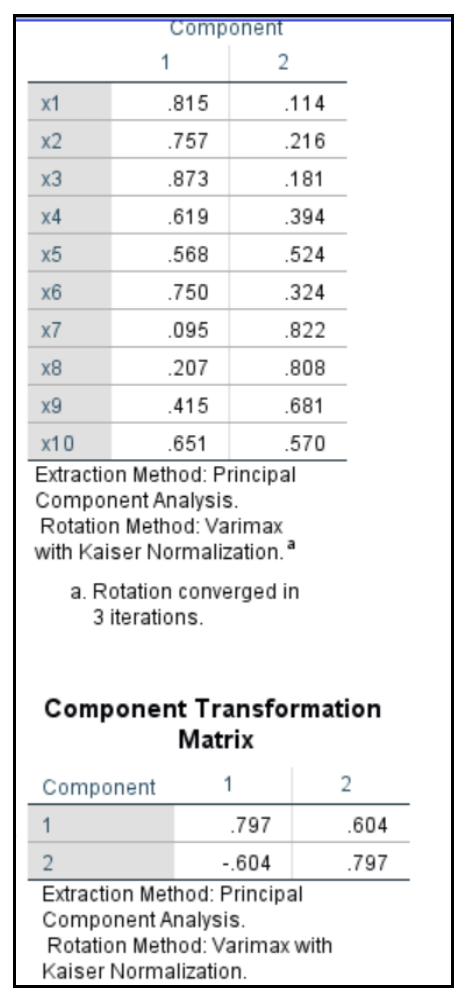

Fig. 3. Component matrix and component transformation matrix.

TABLE IV. GROUPS OF VARIABLE

\begin{tabular}{|c|c|c|c|}
\hline & Variable & Score & $\begin{array}{l}\text { Name of } \\
\text { factors }\end{array}$ \\
\hline \multirow{7}{*}{1} & $\mathrm{X} 1$ - comfortable & 0.815 & \multirow{7}{*}{ Ergonomics } \\
\hline & X2-fashionable & 0.757 & \\
\hline & X3-identity & 0.873 & \\
\hline & X4-symbol & 0.619 & \\
\hline & X5-color & 0.568 & \\
\hline & X6- material & 0.750 & \\
\hline & X10 - ergonomic & 0.651 & \\
\hline \multirow[t]{3}{*}{2} & X7-safety & 0.597 & \multirow[b]{3}{*}{ Syar'i } \\
\hline & X8- syar'i & 0.822 & \\
\hline & $\mathrm{X} 9$ - functional & 0.681 & \\
\hline
\end{tabular}

From the analysis of the factors, the influence of the safety hijab design are ergonomic factors and syar'I factors. It means that beside factor ergonomics (Safety, comfortable, healthy), factor syar'i must be focused in the design. The next step is sketch design with the 2 of characteristic chosen, seen table 5 .

TABLE V. CHARACTERISTIC HIJAB

\begin{tabular}{|l|l|}
\hline \multicolumn{1}{|c|}{ Ergonomic } & \multicolumn{1}{c|}{ Syar'1 } \\
\hline Material is not thick & $\begin{array}{l}\text { the hijab extends over the chest } \\
\text { and is a little loose }\end{array}$ \\
\hline Fit size but little loose & \\
\hline Fashionable & \\
\hline Identity Color (for practical) & \\
\hline Identity sign for practical & \\
\hline
\end{tabular}




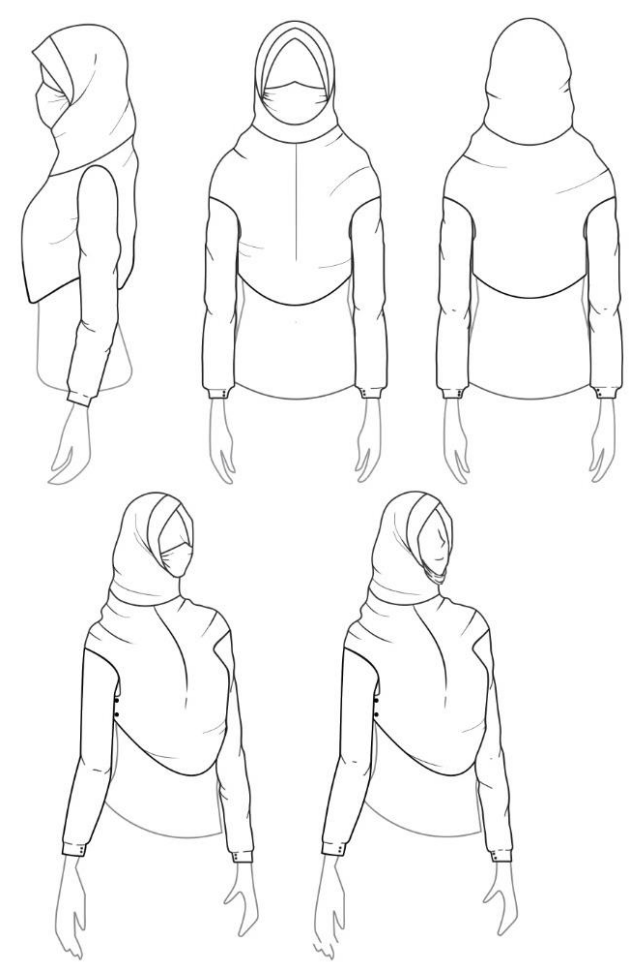

Fig. 4. Sketch design.

\section{CONCLUSION}

From the analysis and discussion, it can be concluded that the design of safety hijab is influenced by ergonomic and syar'I factors. Ergonomics factors are fashionable, comfortable, material, and color. Syar'I factors are the hijab extent over chest. This means that the hijab design applies the provisions of the hijab sticking out over the chest but still paying attention to PPE aspect. The specification of ergonomics is material's not thick, fit size but little bit loose, fashionable, color and symbols identified practical activity. The specification of syar'i are extent over the chest, serve for practical.

\section{ACKNOWLEDGMENT}

We would like to send our biggest gratitude to Politeknik Negeri Samarinda for their efforts and contributions in assisting us in this research.

\section{REFERENCES}

[1] A. Wahyunan, Sutijono, and A. Sholah, "Optimalisasi Penerapan Keselamatan Dan Kesehatan Kerja Pada Laboratorium Jurusan Teknik Mesin Universitas Negeri Malang,” Jurnal Teknik Mesin, vol. 23, no. 2, 2015 .

[2] F. Pangkey, G.Y. Malingkas, and D.R.O. Walangitan, "Penerapan Sistem Manajemen Keselamatan dan Kesehatan Kerja (SMK3) Pada Proyek Konstruksi di Indonesia (Studi Kasus: Pembangunan Jembatan Dr. Ir. Soekarno-Manado),” Jurnal Ilmiah Media Engineering, vol. 2, no. $2,2012$.

[3] G.T. Brito, "Analisis Aspek Pembentuk Budaya K3 Dengan Kepatuhan Penggunaan Apd Pada Pekerja Produksi Resin Di Sidoarjo," The Indonesian Journal of Occupational Safety and Health, vol. 4, no. 2, pp. 134-143, 2015.

[4] G. Gwamba, "Introducing a Health, Safety and Environment Information System towards improved operations HSE planning, monitoring and performance measurement," [online]. Retrieved from https://www.researchgate.net/publication/311234087.

[5] I.K. Muhammad, "Developing a Safety Culture in Developing Countries. Nternational Conference on Safety, Construction Engineering and Project Management," [Online]. Retrieved from 25 https://www.researchgate.net/publication/276488208

[6] A.L. Moh, Design \& Emosi: The Kansei Engineering Methodology. Malaysia: Universitiy Teknologi Mara, 2010.

[7] A. Hadiana, "Design Of Kansei Engineering Support System Using Fuzzy Multiple Attribute Decision Making," International Juornal of Basic and Applied Science, vol. 5, pp. 24-30, 2016.

[8] S.T.W. Schütt, J. Eklund, J.R.C. Axelsson and M. Nagamachi, "Concepts, Methods and Tools in Kansei Engineering," [Online]. Retrieved from https://www.researchgate.net/publication/233349460

[9] V. Mintje, G.Y. Malingkas, D.R.O. Walangitan, and H. Tarore, "Penerapan Sistem Pengendalian Keselamatan Dan Kesehatan Kerja Pada Pelaksanaan Konstruksi (Studi Kasus: Lanjutan Pembangunan Fasilitas Pelabuhan Laut Manado T.A. 2012)," Jurnal Sipil Statik, vol.1, no. 9, pp. 616-622, 2013.

[10] T. Widiatmoko, Prosedur Pelaksanaan Keselamatan Dan Kesehatan Kerja (K3) Pada Pt. Nunas Cipta Agung Semarang. Tugas Akhir. Semarang: Program Diploma III Fakultas Ekonomika Dan Bisnis Universitas Diponegoro, 2017.

[11] S. Solichin, F.E.W. Endarto, and D. Ariwinanti, "Penerapan Personal Protective Equipment (Alat Pelindung Diri) Pada Laboratorium Pengelasan,” Jurnal Teknik Mesin, vol. 22, no. 1, 2014.

[12] L.M. Kurniawidjaja, Teori dan Aplikasi Kesehatan Kerja. Jakarta: UI Press, 2010.

[13] M. Anggrian and S.N. Lathifah, "Komodifikasi Hijab dalam Budaya Visual di Indonesia," PRABANGKARA Jurnal Seni Rupa dan Desain vol. 22, no. 1, 2018.

[14] A.N. Istiani, "Konstruksi Makna Hijab Fashion Bagi Moslem Fashion Blogger,” Jurnal Kajian Komunikasi, vol. 3, no. 1, 2015.

[15] M. Nagamachi, Innovations of Kansei Engineering. 1 st ed., Boca Raton, Florida USA: CRC Press Taylor \& Fancis Group, 2011. 